\title{
TRAFFICKING OF PERSONS FOR THE REMOVAL OF ORGANS AND THE ADMISSION OF GUILT OF A SOUTH AFRICAN HOSPITAL
}

\author{
Jean Allain \\ School of Law, Queen's University, \\ Belfast; Centre for Human Rights, Faculty of Law, \\ University of Pretoria \\ j.allain@qub.ac.uk
}

\section{The State v Netcare Kwa-Zulu (Pty) Limited}

Agreement in Terms of Section 105A(1) of Act 51 of 1977, Netcare

Kwa-Zulu (Proprietary) Limited and the State, Commercial Crime Court, Regional Court of Kwa-Zulu Natal, Durban, South Africa, Case No. 41/1804/2010

\section{Introduction}

In November 2010, under the authority of the South African National Director of Public Prosecution, Netcare Kwa-Zulu (Pty) Limited entered into an agreement ${ }^{1}$ whereby it pleaded guilty to 102 counts related to charges stemming from having allowed its 'employees and facilities to be used to conduct . . . illegal kidney transplant operations'. ${ }^{2}$ Charged along with this private company which was, in fact, the St Augustine's Hospital, located in Durban, South Africa, were the parent company, Netcare, its CEO, Richard Friedland, and eight others: four transplant doctors, a nephrologist, two transplant administrative coordinators, and a translator. The admission of guilt relates to 109 illegal kidney transplant operations which took place between June 2001 and November 2003 within a scheme whereby Israeli citizens in need of kidney transplants would be brought to South Africa for transplants performed at St Augustine's Hospital.

1 The State v Netcare Kwa-Zulu (Proprietary) Limited, Agreement in Terms of s 105 A(1) of Act 51 of 1977, Netcare Kwa-Zulu (Proprietary) Limited and the State, Commercial Crime Court, Regional Court of Kwa-Zulu Natal, Durban, South Africa, Case No 41/1804/2010, 8 November 2010.

2 The State v Netcare Limited, Commercial Crime Court, Regional Court of Kwa-Zulu Natal, Durban, South Africa, Case No 41, 3 September 2010. Summons Charge Sheet, Summary of Substantial Facts, 9. 


\section{Factual Background and Charges to Which Guilt Was Admitted}

While the kidneys supplied originally came from Israeli citizens, "later Romanian and Brazilian citizens were recruited as their kidneys were obtainable at a much lower cost' ${ }^{3}$ The broker, Ilan Perry, the individual who was in charge of the recruitment of both kidney suppliers and recipients - who is not South African and has not been charged - set a fee of between US $\$ 100,000$ and $\$ 120,000$ for recipients and paid the original suppliers of kidneys $\$ 20,000$, though later, the Romanians and Brazilians received on average $\$ 6,000{ }^{4}$

Ilan Perry used recruiters to source individuals ready to supply kidneys; two of these, Captain Ivan Da Silva and Gaby Tauber, have been imprisoned in Brazil for their roles in this affair. Blood screening of prospective kidney suppliers was done in-country and again in South Africa in an attempt to 'ensure sufficient compatibility with prospective recipients'; those deemed suitable were 'accommodated and chaperoned' and 'given documents to sign falsely indicating that they were related to each other'. ${ }^{5}$ This fraudulent activity was meant to circumvent the requirement to gain outside approval, via a Ministerial Committee, for transplants of unrelated principals. While Netcare Kwa-Zulu (Pty) Limited was paid up-front for its participation in the illegal kidney transplants, the people supplying the healthy kidneys were paid after the fact and in cash.

The charges to which Netcare Kwa-Zulu (Pty) Limited pleaded guilty were laid under the South African Human Tissue Act 1983 and the Prevention of Organised Crime Act 1998. It might be mentioned that the company escaped charges which have been levelled at the other accused, including fraud, forgery, and assault with intent to do grievous bodily harm (for operations without informed consent). The Human Tissue Act 1983 prohibits the transplantation of the tissue of minors into another living person; requires that written consent be provided; and that no purchase of tissue, such as kidneys, is allowed. ${ }^{6}$ Further, there exists a Ministerial policy of the Department of Health which sets out, inter alia, that:

Donor organs must be used primarily for South African citizens and permanent residents. Written consent must be obtained from the

\footnotetext{
Ibid, 6.

Ibid, 7.

Ibid, 8.

ss $18(a)$ and 28(1), Human Tissue Act 65 of 1983, 20 May 1983.
} 
Minister of Health before any person who is not a South African citizen or permanent resident is accepted onto a transplantation programme. ${ }^{7}$

The Ministerial policy also establishes that a Ministerial Committee had to approve applications for transplantation of unrelated living donors so as 'to reduce the possibility of abuse ${ }^{8}$ As the Prosecutor relates, the company and the other

accused must have been aware of the law and policy regarding transplants from living donors, and had to try to find a way to portray ostensible compliance with the current policy and legislations. They therefore created the pretence that the kidney suppliers were related to the recipients. ${ }^{9}$

The first charge - counts 1 to 5-to which Netcare Kwa-Zulu (Pty) Limited pleaded guilty related to the use of five minors as organ suppliers in violation of the Human Tissue Act 1983. The employees of St Augustine's Hospital were recognised, in the convoluted Charge Sheet of the Prosecutor, to be 'acting on behalf of the accused company and were about the exercised of their powers and the performance of their duties as employees of the company furthering or endeavouring to further the interests of the company', in carrying out these illegal kidney transplants. ${ }^{10}$ Counts 6 to 10 constituted the second charge and related to receiving payment for the kidney transplants emanating from the five minors. It might be mentioned here that Netcare Kwa-Zulu (Pty) Limited received payments from the broker and it then disbursed payment 'to the other accused and service providers; including the surgeons for their services'. ${ }^{11}$ The third charge, consisting of counts 11

7 The State v Netcare Kwa-Zulu (Proprietary) Limited, Agreement in Terms of s 105A(1) of Act 51 of 1977: Netcare Kwa-Zulu (Proprietary) Limited and the State, Commercial Crime Court, Regional Court of Kwa-Zulu Natal, Durban, South Africa, Case No 41/1804/2010, 8 November 2010, 4-5.

8 Ibid, 4 and 6.

9 The State v Netcare Limited, Commercial Crime Court, Regional Court of Kwa-Zulu Natal, Durban, South Africa, Case No 41, 3 September 2010.

Summons Charge Sheet, Summary of Substantial Facts, 4.

10 The State v Netcare Kwa-Zulu (Proprietary) Limited, Agreement in Terms of s 105A(1) of Act 51 of 1977: Netcare Kwa-Zulu (Proprietary) Limited and the State, Annex A, Charge Sheet, Commercial Crime Court, Regional Court of Kwa-Zulu Natal, Durban, South Africa, Case No 41/1804/2010, 8 November 2010, 2.

11 The State v Netcare Limited, Commercial Crime Court, Regional Court of Kwa-Zulu Natal, Durban, South Africa, Case No 41, 3 September 2010. Summons Charge Sheet, Summary of Substantial Facts, 8. 
through 102, related to contravention of the Prevention of Organised Crime Act 1998.In regard to the 102 transplant operations which did not include minors, the company pleaded guilty to its employees having received money, the proceeds of an unlawful activity; while Netcare Kwa-Zulu (Pty) Limited admitted that 'in the circumstances', it knew 'that the aforementioned property formed part of the proceeds of unlawful activities'. ${ }^{12}$

In the Agreement between Netcare Kwa-Zulu (Pty) Limited and the State, the State recognises its own legitimate interest 'in overseeing the control over transplant of human tissues [. . .] the interests of the medical profession and the public at large'. Where the public interest was concerned, the Agreement notes

that a company, such as the accused company, guilty of an offence such as this, should be convicted and punished and more particularly, that that conviction and punishment should take place in open court for society as a whole to come to know and understand that the prosecuting authorities and the Department of Health will not tolerate breaches of the code of conduct and standards of ethics and compliance with the law required in a civilised society. ${ }^{13}$

The Agreement then sets out the penalty imposed: a confiscation order of $3,800,000$ South African Rand amounting to the benefit the company derived from the offences, plus a sentence of 4,020,000 Rand (in Sterling, respectively, £380,000 and $£ 402,000$ ) amounting to fines for each of the counts to which Netcare Kwa-Zulu (Pty) Limited pleaded guilty.

\section{Relevance}

The Agreement whereby Netcare Kwa-Zulu (Pty) Limited-St Augustine'sHospital —admits guilt to having knowingly allowed its employees and facilities to be used for what amounted to the trafficking of persons for their organs is a landmark, as it constitutes one of the first such cases making its way into a court of law and, in so doing, implicates and effectively prosecutes the hospital involved. The case does not add to the international

12 The State v Netcare Kwa-Zulu (Proprietary) Limited, Agreement in Terms of s 105A(1) of Act 51 of 1977: Netcare Kwa-Zulu (Proprietary) Limited and the State, Commercial Crime Court, Regional Court of Kwa-Zulu Natal, Durban, South Africa, Case No 41/1804/2010, 8 November 2010, 12.

13 The State v Netcare Kwa-Zulu (Proprietary) Limited, Agreement in Terms of s 105A(1) of Act 51 of 1977: Netcare Kwa-Zulu (Proprietary) Limited and the State, Annex A, Charge Sheet, Commercial Crime Court, Regional Court of Kwa-Zulu Natal, Durban, South Africa, Case No 41/1804/2010, 8 November 2010, 13. 
jurisprudence, as South Africa was not party to the 2000 United Nations Palermo Protocol related to trafficking in persons when the material facts took place. ${ }^{14}$ However, it does speak to the legitimate inclusion of provisions dealing with the trafficking in persons for their organs within the definition of trafficking of persons found in the Palermo Protocol, which reads:

'Trafficking in persons' shall mean the recruitment, transportation, transfer, harbouring or receipt of persons, by means of the threat or use of force or other forms of coercion, of abduction, of fraud, of deception, of the abuse of power or of a position of vulnerability or of the giving or receiving of payments or benefits to achieve the consent of a person having control over another person, for the purpose of exploitation. Exploitation shall include, at a minimum, the exploitation of the prostitution of others or other forms of sexual exploitation, forced labour or services, slavery or practices similar to slavery, servitude or the removal of organs. ${ }^{15}$

As Anne Gallagher notes in her The International Law of Human Trafficking, while the provision was 'generally viewed to have been an unnecessary accommodation' during the negotiations of the Palermo Protocol, since then 'the organ trade, including its links with trafficking, has become more apparent and better understood' ${ }^{16}$ This is so, in large part as a result of the work of the medical anthropologist, Nancy Scheper-Hughes. ${ }^{17}$ Likewise the December 2010 report by Dick Marty of the Parliamentary Assembly of the Council of Europe substantiates the claims made by the former Prosecutor of the International Criminal Tribunal for the former Yugoslavia, Carla Del Ponte, that organs were taken from Serbian prisoners of war on orders of the leaders of the Kosovo Liberation Army. As Marty

14 The Republic of South Africa ratified the Protocol to Prevent, Suppress and Punish Trafficking in Persons, Especially Women and Children, Supplementing the United Nations Convention against Transnational Organized Crime on 20 February 2004. See United Nations Treaty Collection at: http://treaties.un.org/pages/ViewDetails.aspx?src=TREATY\&mtdsg no=XVIII-12-a\&chapter=18\&lang=en\#EndDec. accessed 4 January 2011. Art 3(a), Protocol to Prevent, Suppress and Punish Trafficking in Persons, Especially Women and Children, Supplementing the United Nations Convention Against Transnational Organized Crime. Emphasis added. Anne Gallagher, The International Law of Human Trafficking (Cambridge University Press 2010) 41-2.

17 See Nancy Scheper-Hughes, 'Illegal Organ Trade: Global Justice and the Traffic in Human Organs' in Rainer Grussner and Enrico Bedeti (eds), Living Donor Organ Transplants (McGraw Hill 2008), 106-21; Nancy Scheper-Hughes, 'Parts Unknown: Undercover Ethnography of the Organs-Trafficking Underworld' (2004) 5 Ethnography 29; Nancy ScheperHughes and Loïc Wacquant, Commodifying Bodies (Sage Publications 2003); and Nancy Scheper-Hughes, 'The Global Traffic in Human Organs' (2000) 41 Current Anthropology 191. 
concludes, his investigation 'shed light on further, related allegations and draws a very sombre, worrying picture of what took place, and is to some extent continuing to take place, in Kosovo'. ${ }^{18}$ As part of the negotiations which resulted in the plea of guilty by Netcare Kwa-Zulu (Pty) Limited, the charges against Netcare and its CEO, Richard Friedland have been dropped. For his part, Samuel Ziegler, the interpreter, pleaded guilty under the same provisions as Netcare Kwa-Zulu (Pty) Limited in November 2010 and was sentenced to a fine of 50,000 Rand $(£ 5,000)$ or three months imprisonment and given a suspended sentence of five years. ${ }^{19}$ On 15 December 2010,

Dr Jeffrey Kallmeyer, the nephrologist, who acted as the liaison at St Augustine's Hospital, despite having fled from South Africa to Canada, also pleaded guilty to ninety counts and was fined 150,000 Rand $(£ 15,000) .{ }^{20}$ As of January 2011, two transplant administrative coordinators Lindy Dickson and Melanie Azor; and the four transplant surgeons, Ariff Haffejee, John Robbs, Neil Christopher, and Mahadev Naidoo, await trial.

While the trafficking of persons for their organs has stopped in South Africa as a result of the charges laid in relation to the kidney transplant operations taking place at St Augustine's Hospital in Durban, it appears that such illegal transplants were also taking place in Cape Town and Johannesburg. The extent to which those within the medical establishment in South Africa conducting organ transplants were involved in the illegal harvesting of organs for profit appears to have been widespread. At St Augustine's Hospital, over a hundred times, in side-by-side surgical theatres, two foreigners, speaking different languages were operated upon: one affluent, older and ill; the other poor, young (in five cases, a child), but healthy. That the practice persisted for more than two years without anybody, the surgeons, the doctors, the scrub nurses, the administrators, or the blood technicians, bringing these illegal activities to the attention of the police is an indictment of the profession. It remains to be seen whether, like Netcare Kwa-Zulu (Pty) Limited, the other accused will be found guilty for their part in trafficking people from Europe, the Middle East and South America to the African continent so as to exploit them by removing their organs for profit.

18 Council of Europe, Parliamentary Assembly, Committee on Legal Affairs and Human Rights, 'Inhuman Treatment of People and Illicit Trafficking in Human Organs in Kosovo', Draft Report, Dick Marty, Rapporteur, AS/Jur (2010) 46, 12 December 2010, para 175.

19 The State v Samuel Ziegler, Agreement in Terms of s 105A of the Criminal Procedure Act 1977, Commercial Crime Court, Regional Court of Kwa-Zulu Natal, Durban, South Africa, Case No 41/1816/2010, 23 November $2010,8$.

${ }^{20}$ South Africa Police Service, 'Police Secure further Conviction in Human Organ Transplant case', 15 December 2010, See South African Government Information at:http://www.info.gov.za/speech/DynamicAction?pageid=461\&sid=15306\&tid=2 5900. accessed 4 January 2011. 